UNPAD

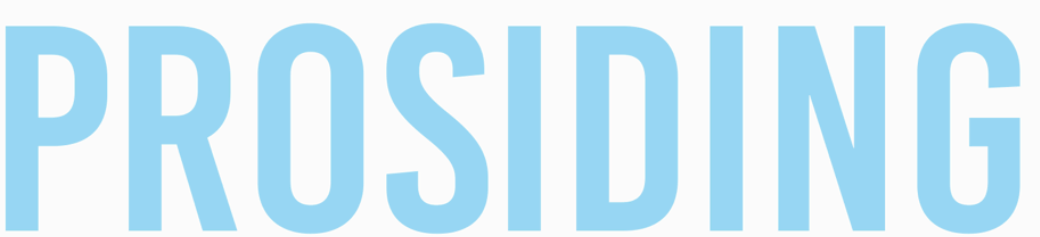

Fakultas Pertanian Universitas Padjadjaran

SEMINAR NASIONAL PEMANFAATAN TANAMAN LOKAL UNTUK PANGAN DAN INDUSTRI

3 August 2017 

Seminar Nasional “Pemanfaatan Tanaman Lokal untuk Pangan dan Industri” 2017:

3 Agustus 2017, Jatinangor, Indonesia

\section{PROSIDING SEMINAR NASIONAI DEPARTEMEN BUDIDAYA PERTANIAN 2017}

Tema:

Pemanfaatan Tanaman Lokal untuk Pangan dan Industri

Sub Tema :

Pemuliaan dan Teknologi Benih

Produksi Tanaman dan Lingkungan

Pasca Panen dan Pengolahan

Functional Food

Cetakan pertama

ISBN : 978-602-439-223-9

Sanksi pidana atas pelanggaran Hak Cipta: dalam Undang-Undang R.I. No.19 tahun 2002 :

Pasal 72

1. Barang siapa dengan sengaja dan tanpa hak melakukan perbuatan sebagaimana dimaksud dalam Pasal 2 ayat (1) atau Pasal 49 ayat (1) dan ayat (2) dipidana dengan pidana penjara masing-masing paling singkat 1 (satu) bulan dan / atau denda paling sedikit Rp.1.000.000,00 (satu juta), atau pidana penjara paling lama 7 (Tujuh) tahun dan / atau denda paling banyak Rp.5.000.000.000,00 (lima milyar rupiah).

2. Barang siapa dengan sengaja menyiarkan, memamerkan, mengedarkan, atau menjual kepada uтum suatu Ciptaan atau barang hasil pelanggaran Hak Cipta atau Hak Terkait sebagaimana dimaksud pada ayat (1) dipidana dengan pidana penjara paling lama 5 (lima) tahun dan / atau denda paling banyak Rp.500.000.000,00 (lima ratus juta rupiah).

UNPAD PRESS

Gedung Rektorat Lantai IV

Universitas Padjadjaran

JI. Raya Bandung - Sumedang Km 21

Jatinangor Sumedang

Telp (022) 84288812 Fax (022) 84288896

Copyright (C) 2017,

Hak cipta dilindungi undang-undang. Dilarang memperbanyak karya tulis ini dalam bentuk dan dengan cara apapun tanpa ijin tertulis dari penerbit 


\title{
PERUBAHAN KUALITAS OYONG SELAMA PENYIMPANAN
}

\author{
Kusumiyati $^{1)}$, Farida $^{1)}$, Wawan Sutari ${ }^{1)}$, Syariful Mubarok ${ }^{1)}$ \\ Ine Elisa Putri ${ }^{2)}$, Yuda Hadiwijaya ${ }^{2)}$ \\ ${ }^{1)}$ Staf Pengajar Program Studi Agroteknologi Fakultas Pertanian Universitas Padjadjaran \\ 2) Alumni Program Studi Agroteknologi Fakultas Pertanian Universitas Padjadjaran \\ E-mail: Kusumiyati@gmail.com \\ Jurusan Agroteknologi Fakultas Pertanian Universitas Padjadjaran \\ Jl. Raya Bandung-Sumedang KM. 21 Jatinangor 40600 Tlp. 022-7796320/Fax. 022-7796316
}

\begin{abstract}
ABSTRAK
Oyong (Luffa acutangula) adalah tanaman dari famili Cucurbitaceae yang banyak di budidayakan di Indonesia. Kualitas oyong selama proses pendistribusian dari petani ke pasar hingga ke tangan konsumen/ dikonsumsi akan terjadi penurunan bila tidak ada penanganan yang sesuai. Hal ini menjadi alasan perlunya dilakukan penelitian lama simpan oyong serta perubahan kualitasnya dikarenakan adanya proses pendistribusian sampai dikonsumsi. Tujuan dilakukan penelitian ini adalah untuk menguji perubahan kualitas oyong selama masa penyimpanan. Penelitian dilakukan mulai Bulan Maret sampai Bulan Juli 2017 di Laboratorium Teknologi Produksi Tanaman Divisi Hortikultura Fakultas Pertanian Universitas Padjadjaran di Jatinangor, Sumedang, Jawa Barat. Metoda percobaan yang digunakan adalah Rancangan Acak Kelompok (RAK) dengan tiga perlakuan dan 9 ulangan. Ketiga perlakuan tersebut yaitu penyimpanan 0 Hari Setelah Panen (HSP), penyimpanan 5 HSP dan penyimpanan $10 \mathrm{HSP}$ di suhu kamar. Pada masing-masing ulangan terdapat 10 sampel sehingga total sampel sebanyak 270 buah. Hasil penelitian menunjukkan terjadinya perubahan kualitas oyong selama penyimpanan sampai 10 hari pada karakter warna buah $\left(\mathrm{L}^{*}\right.$, $\mathrm{b}^{*}$, ${ }^{\circ}$ hue, chroma), kadar air, susut bobot, dan texture, namun tidak terjadi perubahan pada karakter warna buah $\mathrm{a}^{*}$, total padatan terlarut dan kekerasan buah.
\end{abstract}

Kata Kunci: Chroma, Hue, Kekerasan Buah, Tekstur, Total Padatan Terlarut, 


\title{
CHANGES OF LOFAAH QUALITY DURING STORAGE
}

\author{
Kusumiyati $^{1)}$, Farida $^{1)}$, Wawan Sutari ${ }^{1)}$, Syariful Mubarok ${ }^{1)}$ \\ Ine Elisa Putri ${ }^{2)}$ dan Yuda Hadiwijaya ${ }^{2)}$ \\ ${ }^{1)}$ Lecture Agrotechnology Study Program Faculty of Agriculture, Padjadjaran University \\ ${ }^{2)}$ Alumni Program Studi Agroteknologi Fakultas Pertanian Universitas Padjadjaran \\ E-mail: Kusumiyati@gmail.com
}

Jurusan Agroteknologi Fakultas Pertanian Universitas Padjadjaran

Jl. Raya Bandung-Sumedang KM. 21 Jatinangor 40600 Tlp. 022-7796320/Fax. 022-7796316

\begin{abstract}
Ridge gourd (Luffa acutangula) is one of members Cucurbitaceae family that are many cultivated in Indonesia. The quality of ridge gourd probably decreases during distribution from the farmer to the market then to consumer if there is not apropriate handling. The Research on how long ridge gourd can be stored and how is the quality changes are needed. The aim of the research was to analyze the quality changes of ridge gourd during storage. The experiment was conducted from March to July 2017 at the Laboratory Plant Production Technology of Horticulture Division of the Faculty of Agriculture of Padjadjaran University, Sumedang, West Java. The experimental design used in this experiment was Randomize Block Designed (RBD) with three treatments and 9 replications. The three treatments were for 0 days after harvest (DAH), 5 DAH and 10 DAH stored indoor at room temperature. In each replication there were 10 samples that the total samples were 270 pieces. The results showed that the quality of Ridge gourd during storage changes until ten days on fruit color $\left(L^{*}, b^{*}\right.$, hue, chroma), moisture content, and texture, however the changes were not happen for fruit color $a^{*}$, total dissolved solid and fruit firmness.
\end{abstract}

Keywords: Chroma, hue, firmness, texture, total soluble solid 


\section{PENDAHULUAN}

Oyong (Luffa acutangula) adalah tanaman dari famili Cucurbitaceae yang asalnya dari India, namun telah banyak dibudidayakan di Indonesia (Sumpena, 2010). Potensi pasar oyong dinilai cukup baik dan permintaan konsumen meningkat sejalalan dengan kesadaran masyarakat akan kesehatan untuk mengonsumsi sayuran oyong maupun digunakan sebagai obat.

Para konsumen melakukan penilaian kualitas sayuran biasanya dilihat dari ukuran, bentuk, rasa, tekstur atau kekerasan buah, bebas dari kerusakan, dan benda asing lainnya (Chen and Sun, 1991). Oyong memiliki karakteristik kulit yang keras sehingga dapat meminimalisir kerusakan yang tejadi dari mulai pemanenan sampai diterima oleh konsumen. Kekerasan buah merupakan karakteristik fisik yang sering digunakan untuk menilai kualitas sayuran maupun buah-buahan.

Proses dari pemanenan oyong hingga diterima oleh konsumen tentunya tidak dapat dilakukan secara langsung dalam satu hari. Setelah dipanen, oyong melalui beberapa proses distribusi dari pasar lokal di dalam maupun luar kota dari tangan petani hingga pedagang, sampai ke tangan konsumen memerlukan waktu hingga 5 hari. Ditangan konsumen diharapkan masih layak dikonsumsi dalam kurun waktu sampai 10 hari. Sehingga masa penyimpanan oyong perlu diteliti lebih lanjut, agar konsumen masih mendapatkan kualitas oyong yang diinginkan.

Komponen kualitas yang diamati adalah warna buah $\left(\mathrm{L}^{*}, \mathrm{a}^{*}, \mathrm{~b}^{*}\right.$, hue dan chroma), kekerasan buah, kadar air, total padatan terlarut dan tekstur analisis. Perubahan warna buah akan terjadi selama masa penyimpanan dilakukan. Total padatan terlarut menjadi salah satu indikator yang penting untuk diukur selama waktu penyimpanan, ada beberapa komoditas tertentu yang mengalami kenaikan total padatan terlarut selama masa penyimpanan. Kadar gula buah Jeruk Siam pada penyimapanan 5 dan 10 hari mengalami kenaikan dibanding kontrol (Helmiyesi $d k k$., 2008). Kriteria kualitas pada buah dan sayur ditentukan oleh kandungan kimianya seperti total padatan gula terlarut, kandungan air, serta kandungan gula dan komposisinya (Saltveit, 2005). Semakin lama waktu penyimpanan yang diberikan maka akan semakin banyak perubahan pada zat warna buah (Desrosier, 1988). Buah oyong memiliki kulit yang keras, sehingga perlu dilakukan pengujian kekerasan buah. Kerutan pada buah menjadi salah satu indikator yang mempengaruhi tingkat kekerasan pada buah. Faktor lainnya yang dapat berpengaruh ialah kandungan pati, total padatan terlarut dan ketebalan buah (Pantastico, 1986). Selama masa penyimpanan buah atau sayuran dapat pula terjadi penurunan kadar air (Kader, 2002). Untuk itu perlu dilakukan pengujian kadar air hingga bahan uji mencapai berat yang konstan. Total padatan terlarut menjadi salah satu indikator penilaian.

Berdasarkan uraian diatas maka dilakukan penelitian mengenai perubahan tekstur dan warna yang terjadi selama pengolahan terhadap kandungan air dan total padatan terlarut pada buah oyong yang dapat dijadikan sebagai penentu kualitas buah oyong selama masa penyimpanan.

\section{BAHAN DAN METODA}

Penelitian dilakukan mulai Bulan Maret 2017 sampai Bulan Juli 2017 di Laboratorium Teknologi Produksi Tanaman Divisi Hortikultura Fakultas Pertanian Universitas Padjadjaran di Jatinangor, Sumedang, Jawa Barat. Metoda percobaan yang digunakan adalah Rancangan Acak Kelompok (RAK). Perlakuan yang digunakan adalah masa penyimpanan selama 0 HSP (Hari Setelah Panen), 5 HSP dan 10 HSP. Total terdapat 3 perlakuan dengan 9 kali ulangan. Pada masing-masing ulangan terdapat 10 sampel sehingga total sampel sebanyak 270 buah. Analisis statistik menggunakan software SPSS 17. Bahan yang digunakan adalah 270 sampel buah oyong. Alat yang digunakan adalah oven (Jouan EB.100, Germany), chromameter (Konica Minolta, Japan), refraktometer (PR1 Atago, Japan), tension gauge (AND Model AD-4932A-50 N, Taiwan), alummunium foil, parutan dan pisau.

Warna buah diukur dengan menggunakan chroma meter (Gambar 2), bertujuan untuk dapat melihat perubahan warna buah yang terjadi selama masa penyimpanan. Teknik pengukuran dilakukan dengan cara menempelkan kulit sampel ke sensor spektral, lalu klik tombol sehingga muncul angka digital 
berupa $\mathrm{L}^{*}, \mathrm{a}^{*}$ dan $\mathrm{b}^{*}$. Kekerasan buah diukur dengan menggunakan tension gauge (Gambar 3) dengan cara menusukkan alat ke buah sampel, satuan yang digunakan Newton $(\mathrm{N})$. Pengukuran kadar air dilakukan untuk menurunkan kandungan air dalam bahan yang diujikan.

Pengukuran kadar air dengan metode gravimetri menggunakan oven (Gambar 4) dapat dimanfaatkan untuk mempercepat pelepasan kandungan air terhadap bahan yang diuji (Desrosier, 1988). Pengujian kadar air dilakukan dengan memotong buah oyong menjadi ukuran yang lebih kecil sehingga dapat dimasukkan ke dalam aluminium foil dan masukkan ke oven hingga mendapatkan berat yang konstan. Total padatan terlarut diukur dengan menggunakan alat refractometer (Gambar 1). Sampel buah oyong dipotong kemudian ekstrak cairan dan teteskan pada prisma refractometer sebanyak tiga ulangan setiap sampel. Skala refractometer menunjukan kadar total padatan terlarut (\%Brix).

Analisis tekstur diukur dengan menggunakan alat texture analyzer. Pengukuran tekstur lebih objektif jika dibandingkan dengan pengukuran kekerasan buah yang menggunakan tension gauge, hal ini disebabkan tension gauge pengukurannya masih menggunakan bantuan tenaga manusia. Keakuratan pengukuran akan meningkatkan kontrol kualitas pada bahan uji (Leon et al., 2005)

\section{HASIL DAN PEMBAHASAN}

Lamanya penyimpanan berpengaruh terhadap nilai $\mathrm{L}^{*}$ (Tabel 1). Penyimpanan 5 dan penyimpanan 10 hari berbeda nyata dengan penyimpanan 0 menghasilkan nilai $\mathrm{L}^{*}$ yang lebih terang, hal ini menandakan kulit oyong mengalami perubahan kecerahan selama penyimpanan. Perubahan warna terjadi kerena hilangnya klorofil dan mulai muncul karetonoid (Syafutri dkk., 2006).

Pada Tabel 2 menunjukkan tidak ada perbedaan nyata antara berbagai masa penyimpanan terhadap nilai ${ }^{*}$. Lamanya penyimpanan yang negatif menandakan warna oyong masih relatif hijau hingga penyimpanan 10 hari. Nilai a ${ }^{*}$ yang negatif mengindikasikan warnanya lebih mengarah ke hijau, sementara a ${ }^{*}$ yang positif menunjukkan warna merah. Oyong merupakan sayuran hijau yang lebih tahan terhadap perubahan warna karena kulitnya yang relative tebal dan permukaannya yang kasar.

Semakin lama penyimpanan menghasilkan nilai $b^{*}$ lebih tinggi, terlihat pada Tabel 3 yang menunjukkan perbedaan yang nyata untuk setiap perlakuan. Peningkatan ini membuktikan kulit oyong semakin lama mengarah ke kuning, karena nilai $b^{*}$ yang positif mengarah pada warna kuning, dibandingkan nilai $b^{*}$ yang negative lebih mengarah ke biru. Semakin di simpan dengan rentang 5 hari semakin tampak perubahan warna kuning yang lebih kuat.

Nilai ${ }^{\circ}$ hue pada Tabel 4 menunjukkan perbedaan yang nyata di setiap berbagai jenis lamanya penyimpanan. Nilai ${ }^{\circ}$ hue dari 0 HSP ke 5 HSP berbeda nyata dan semakin menurun menyatakan warna hijau yang lebih dominan dibanding warna kuning. Dari 5 HSP ke 10 HSP pun berbeda nyata dan semakin menurun tetapi masih tetap dinyatakan dalam warna hijau.

Chroma merupakan penjumlahan dari akar kuadrat dari nilai $\mathrm{a}^{*}$ kuadrat dan nilai $\mathrm{b}^{*}$ kuadrat. Hasil perhitungan nilai chroma rendah atau mendekati negatif menunjukkan kekusaman warna buah oyong. Lamanya penyimpanan berpengaruh terhadap kekusaman warna buah oyong. Makin lama disimpan buah oyong. semakin hilang warna kusamnya. Penyimpanan 10 hari memiliki nilai chroma yang lebih tinggi dibandingkan penyimpanan 0 HSP dan 5 HSP (Tabel 5).

Lama peyimpanan tidak menunjukkan perbedaan yang nyata tehadap nilai total padatan terlarut (TPT) pada oyong berdasarkan analisis ragam. Nilai TPT yang tidak berbeda nyata menunjukkan tidak terdapat perubahan padatan terlarut total secara signifikan. Kisaran nilai total padatan terlarut pada 0 HSP hingga 10 HSP berada pada nilai $3.46 \%$ Brix hingga $3.54 \%$ Brix (Tabel 6). 
Kadar air penyimpanan 5 dan 10 hari berbeda nyata dengan penyimpanan 0 hari. Nilai kadar air penyimpanan 0 hari lebih tinggi jika dibandingkan dengan perlakuan lainnya, hal ini dikarenakan evaporasi dan respirasi pada penyimpanan 5 dan 10 hari lebih tinggi sehingga menyebabkan kandungan airnya berkurang (Tabel 7). Evaporasi dan respirasi menyebabkan susut bobot bertambah nilainya hal ini terlihat bila buah oyong di belah akan tampak cekungan. Susut bobot dapat terlihat pada grafik 1. Perubahan bentuk fisik oyong dari 0 HSP dan 10 HSP dapat dilihat di gambar 1.

Pengaruh lama penyimpanan oyong tidak berbeda nyata terhadap nilai kekerasan buah untuk setiap perlakuan. Pada Tabel 8 menunjukkan tidak ada perbedaan yang nyata disetiap perlakuan. Oyong memiliki kulit yang keras dan relatif agak tebal sehingga tidak menyebabkan perbedaan nilai kekerasan buah walaupun disimpan hingga 10 hari. Sifat oyong yang termasuk ke dalam golongan non klimaterik memungkinkan buah ini tidak mengalami kenaikan laju respirasi yang signifikan setelah pemanenan, sehingga walaupun dilakukan penyimpanan hingga 10 hari tidak ada perubahan kekerasan pada kulit buah.

Tekstur menunjukkan perbedaan yang nyata pada perlakuan penyimpanan 0 hari terhadap penyimpanan $10 \mathrm{HSP}$ dan tidak berbeda nyata pada perlakuan $5 \mathrm{HSP}$. Tekstur buah oyong pada saat di panen masih tinggi, sejalan dengan lamanya penyimpanan dimana buah kehilangan kadar air akibat evaporasi dan respirasi, sehingga pada 10 HSP tampak teksturnya menurun (menjadi empuk).

Penggunaan tension gauge dan texture analyzer bertujuan untuk mengukur kekerasan buah oyong, tetapi hasil analisis dari kedua alat tersebut menunjukkan perbedaan nilai. Hal ini disebabkan tension gauge diukur dengan menggunakan tenaga manusia secara manual, sementara texture analyzer pengukurannya secara otomatis dengan alat sehingga hasilnya lebih objektif.

\section{KESIMPULAN}

Kualitas oyong selama masa penyimpanan sampai dengan 10 HSP masih menunjukkan layak dikonsumsi dengan tidak terdapatnya perubahan komponen total padatan terlarut, warna buah $\mathrm{a}^{*}($ hijau) dan kekerasan. Berbagai komponen yang mengalami perubahan selama penyimpanan sampai dengan $10 \mathrm{HSP}$ adalah nilai $\mathrm{L}^{*}, \mathrm{~b}^{*}$, ${ }^{\mathrm{h}}$ hue, chroma, kadar air dan tekstur.

\section{DAFTAR PUSTAKA}

Chen, P.; Z. Sun. (1991) A Review of Non-destructive Methods for Quality Evaluationand Sorting of Agricultural Products. J. agric. Engng Res. 49, 85-98.

Desrosier, N. W. (1988) Teknologi Pengawetan Pangan. Universitas IndonesiaPress. Jakarta.

Helmiyesi, R. B. Hastuti dan E. Prihastanti (2008) Pengaruh Lama Penyimpanan Terhadap Kadar Gula dan Vitamin C pada Buah Jeruk Siam (Citrus nobilis var. microcarpa). Buletin Anatomi dan Fisiologi XVI.

Kader, A.A. (2002) Postharvest technology of horticultural crops: an overview. In: Postharvest Technology of Horticultural Crops (A.A. Kader, ed.). University of California, Davis, USA. p. 41-285.

kementrian pertanian. [Online] Diakses dari http://balitsa.litbang.pertanian.go.id [9 Juli 2017].

Leon, K., D. Mery and F.Pedreschi. (2005) Color Measurements in L*a*b* Unit from RGB Digital Unit. Universidad de Santiago de Chile (USACH), Santiago. 
Kusumiyati, Farida, Wawan Sutari, Syariful Mubarok, Ine Elisa Putri, Yuda Hadiwijaya/ Perubahan kualitas oyong selama penyimpanan

Pantastico, Er. T.L. Chattpadhayay dan H. Subramayan. (1986) Fisiologi Pasca Panen. Gadjah Mada University Press. Yogyakarta.

Saltveit, M.E. (2005) Fruit Ripening and Friut Quality. In Heuvenlik Ep (Ed).

Sumpena. (2010) Budidaya Oyong. Balai Penelitian dan pengembangan pertanian

Syafutri, M.I., F. Pratamadan D. Saputra. (2006) Sifat dan Kimia Buah Mangga (Mangiferaindica L.) Selama Penyimpanan dengan Berbagai Metode Pengemasan. Jurnal Teknologi dan Industri Pangan XVII (1). 


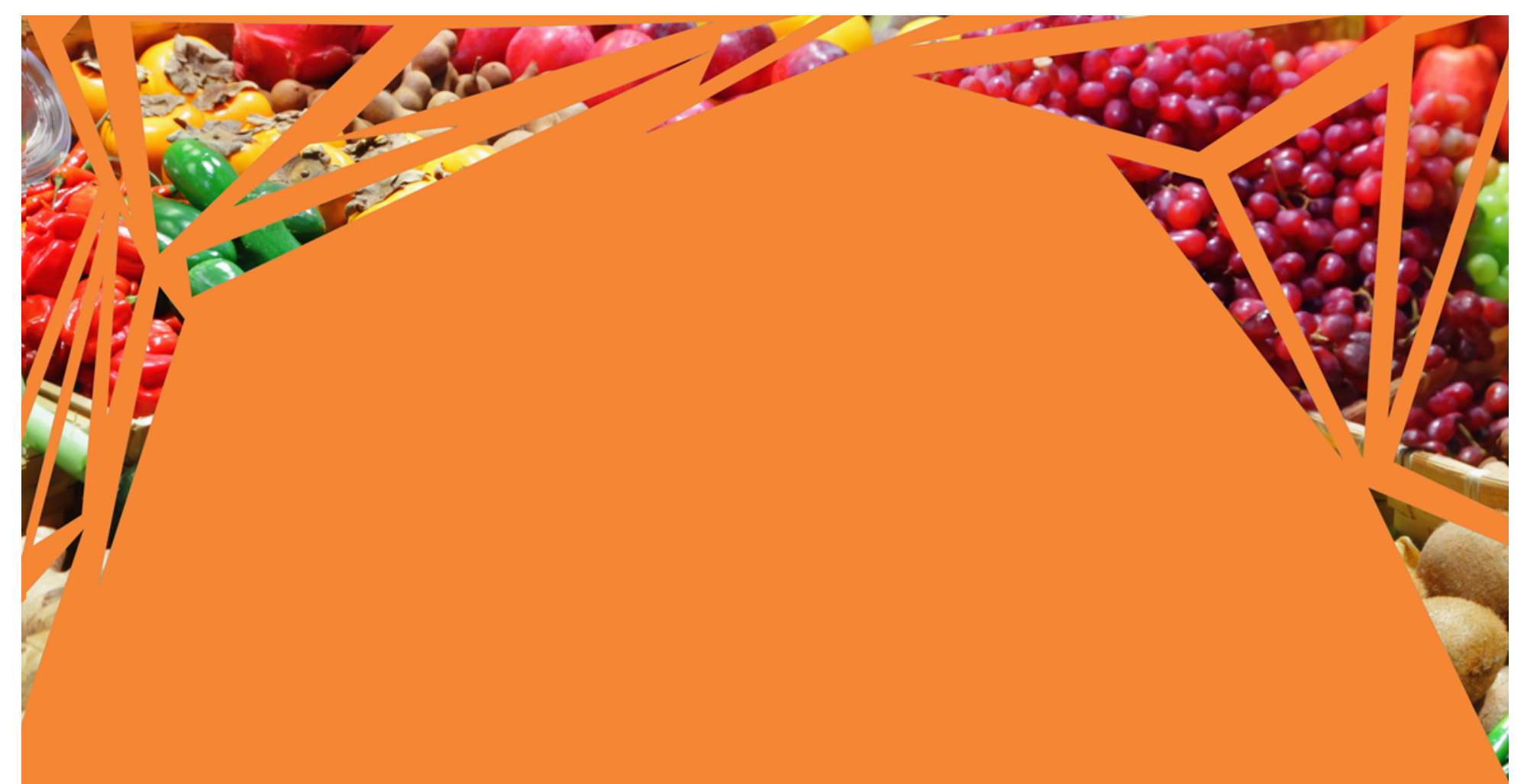

